\title{
Properties of Whey Protein-Based Films Containing Organic Acids and Nisin To Control Listeria monocytogenes
}

\author{
CRISTINA M. B. S. PINTADO, ${ }^{1,2 *}$ MARIA A. S. S. FERREIRA, ${ }^{2}$ AND ISABEL SOUSA ${ }^{2}$ \\ ${ }^{1}$ Escola Superior Agrária, Instituto Politécnico de Castelo Branco, Quinta da Senhora de Mércoles, 6001-909 Castelo Branco, Portugal; and 2 Instituto \\ Superior de Agronomia, Technical University of Lisbon, Tapada da Ajuda, 1349-017 Lisboa, Portugal
}

MS 09-074: Received 15 February 2009/Accepted 22 April 2009

\begin{abstract}
Whey protein isolate and glycerol were mixed to form a matrix to incorporate antimicrobial agents and produce edible films with antimicrobial activity against Listeria monocytogenes strains isolated from cheeses. Various organic acids were used to decrease $\mathrm{pH}$ down to approximately 3. In a preliminary assay without nisin, the effect of each organic acid was evaluated with respect to the rheological properties of the film solutions and the inhibitory and mechanical properties of the films. Lactic, malic, and citric acids $(3 \%, \mathrm{wt} / \mathrm{vol})$, which were used in a subsequent study of their combined inhibitory effect with nisin $(50 \mathrm{IU} / \mathrm{ml})$, had significantly higher antilisterial activity $(P<0.05)$ compared with the control $(2 \mathrm{~N} \mathrm{HCl}, 3 \%$ [wt/vol], with nisin). The largest mean zone of inhibition was $4.00 \pm 0.92 \mathrm{~mm}$ for malic acid with nisin. Under small-amplitude oscillatory stress, the proteinglycerol-acid film solutions exhibited a predominantly viscous behavior or a weak gel behavior, with the storage modulus $\left(\mathrm{G}^{\prime}\right)$ slightly higher than the loss modulus $\left(\mathrm{G}^{\prime \prime}\right)$. The malic acid-based solution was the only one whose viscosity was not influenced by the addition of nisin. The addition of nisin resulted in a nonsignificant $(P>0.05)$ increase in the percentage of elongation at break. Results from tensile and puncture stress were variable, but in general no significant differences were found after the incorporation of nisin. The overall results support the use of malic acid with nisin to produce effective antimicrobial films to control L. monocytogenes growth.
\end{abstract}

The use of bioactive films to wrap and protect cheese is common in the industry. The most frequently used coatings probably are those based on polyvinyl acetate and polyvinyl alcohol, but the safety of these products has been discussed (9). Films based on whey protein isolate (WPI) are a promising alternative because this material is edible, has high chemical affinity for the cheese surface, and is a byproduct of the cheese industry with a high impact as a pollutant waste. Approximately $10^{8} \mathrm{~kg} / \mathrm{year}$ of liquid whey is produced in Portugal; therefore its use needs to be promoted for environmental reasons.

The best protocol for making whey protein films, as studied by McHugh et al. (11), is $10 \%$ (wt/wt) aqueous protein solution at neutral $\mathrm{pH}$ heated for $30 \mathrm{~min}$ at $90^{\circ} \mathrm{C}$. The heat denaturation is required to open the globular structure of the whey proteins, break the disulfide bonds, and form new intermolecular disulfide and hydrophobic bonds, resulting in a water-insoluble whey protein-based film (11). Because the combination of resulting intermolecular disulfide bonds and intermolecular interactions between protein chains based on hydrogen bonding, hydrophobic interactions, and electrostatic forces produces brittle films (17), plasticizers must be added. These additives overcome brittleness by reduction of protein chain-to-chain interaction and an increase of polymer-plasticizer hydrogen bonds.

Nisin is an amphiphilic polypeptide produced by certain strains of Lactococcus lactis subsp. lactis. The

\footnotetext{
* Author for correspondence. Tel: +351272339900 ; Fax: +351272339901 ; E-mail: cpintado@esa.ipcb.pt.
}

antimicrobial activity of nisin inhibits a wide range of grampositive bacteria (6). A double mode of action of nisin was reported by Ryan et al. (16). Nisin binds to lipid II, inhibiting cell wall synthesis and forming pores in the cytoplasmic membrane. As a natural food preservative, nisin is currently permitted in the European Union according to Directive 95/2/EC (2) at the levels of $12.5 \mathrm{mg} / \mathrm{kg}$ in ripened cheese and processed cheese. Although formation of WPI films is favored in more alkaline filmogenic solutions (3), most antimicrobial agents, such as nisin, are more effective under acidic conditions. The stability, solubility, and activity of nisin are greatest at low $\mathrm{pH}$ (15). Like nisin, organic acids have antimicrobial activity and are classified as generally recognized as safe, compatible with their use in the development of an edible antimicrobial coating.

The purpose of the work reported here was to study and characterize the solutions and the films made with WPI as a biopolymer, glycerol as plasticizer, and various organic acids with and without nisin as antimicrobial agents to control Listeria monocytogenes. An understanding of the relative influence of various acidulants and nisin on whey protein-based film properties will allow researchers to select a formulation that provides the most effective film for wrapping and protecting cheeses.

\section{MATERIALS AND METHODS}

Preparation of film solutions and films. Seven grams of WPI (92\% minimum protein content, dry basis; Carbery Group, Ballineen, Ireland) was dissolved and homogenized in $100 \mathrm{ml}$ of 
distilled water and stirred with a magnetic bar for $15 \mathrm{~min}$, and $3.0 \mathrm{~g}$ of glycerol (Sigma-Aldrich Chemical Co., St. Louis, MO) was introduced to the solution and stirred again for $15 \mathrm{~min}$. Each organic acid (acetic acid, Merck, Darmstadt, Germany; malic acid, BDH Chemicals Ltd., Poole, UK; citric, ascorbic, and formic acids, Panreac, Barcelona, Spain; lactic acid, Riedel-de-Haën, Seelze, Germany; fumaric acid, Sigma-Aldrich), at 1.5 and $3.0 \%$ (wt/vol), was added, and the final solution was stirred for $15 \mathrm{~min}$ until uniform solutions were obtained. As a $\mathrm{pH}$ control, 3.0\% (wt/vol) $2 \mathrm{~N} \mathrm{HCl}$ (Riedel-de-Haën) was used. After measuring the $\mathrm{pH}$, the solutions were heated at $90^{\circ} \mathrm{C}$ for $30 \mathrm{~min}$ in a shaking water bath. Once cooled at room temperature, an adequate volume of nisin solution at $10^{5} \mathrm{IU} / \mathrm{ml}$ (nisin $\mathrm{NP}$, Danisco, Beaminster, UK) previously made with $20 \mathrm{mM} \mathrm{HCl}$ was incorporated to produce a final concentration of $50 \mathrm{IU} / \mathrm{ml}$. This concentration was previously determined as the lowest concentration tested that gave complete growth inhibition of L. monocytogenes strains used in this assay (data not shown). Films were cast by aseptically pipetting $9 \mathrm{ml}$ of solution into 90 -mm polystyrene disposable plates. After drying for 24 to $48 \mathrm{~h}$ at $23 \pm 2{ }^{\circ} \mathrm{C}$ and $50 \% \pm 5 \%$ relative humidity, the films were peeled from the plates and stored under the same controlled conditions until used.

Rheological measurements. The rheological measurements were performed in a controlled-stress rheometer (RS75, Haake, Karlsruhe, Germany) at $20 \pm 0.1^{\circ} \mathrm{C}$, using serrated parallel plate geometry (PP35 or PP60) to overcome the slip effect and a gap of $1.000 \mathrm{~mm}$. Oscillatory tests (mechanical spectra) were carried out using a frequency range of 0.01 to $100 \mathrm{~Hz}$ and a stress value in the linear viscoelastic region for each solution (1 to $20 \mathrm{~Pa}$ ). Steadystate flow measurements were also made, and viscosity versus shear stress curves were constructed using a logarithmic ramp of stresses increasing from 0.001 to $2,300 \mathrm{~Pa}$. In all cases, at least two measurements were made.

Mechanical properties of films. Tensile strength was measured with a TA-XTplus Texture Analyser (Stable Micro Systems, Godalming, UK). The films were cut into strips $70 \mathrm{~mm}$ long and $20 \mathrm{~mm}$ wide and selected for lack of defects, and the film thickness was measured with a micrometer with a sensitivity of $0.01 \mathrm{~mm}$ (Absolute Digimatic Calliper, Mitutoyo Ltd, Andover, UK) at six or more random locations to obtain the mean thickness. These film strips were mounted in the film-extension grips, tensile grips $\mathrm{A} / \mathrm{TG}$, of the texture analyzer and stretched at a speed of $0.8 \mathrm{~mm} / \mathrm{s}$ in tension mode. Tensile stress (in megapascals) was calculated as the ratio of the peak load developed during the test by the film cross-sectional area (sample width times sample thickness). The percentage of elongation at break was calculated as the ratio of the extension of the specimen at the moment of rupture by the initial gage length, multiplied by 100 . At least 15 measurements were taken. The puncture strength of the films was measured on a texturometer TA-XT2 (Stable Micro Systems) by mounting square film strips (30 by $30 \mathrm{~mm}$ ) on a specially designed base with a hole $9.89 \mathrm{~mm}$ in diameter. With a cylindrical $2-\mathrm{mm}$ probe and a test speed of $2.0 \mathrm{~mm} / \mathrm{s}$ in compression mode, the films were punctured through the hole and the force (in Newtons) at the point of rupture was recorded; this value divided by the probe contact area was expressed as the puncture stress. The percentage of elongation at puncture also was calculated. All mechanical tests were performed at least 15 times at $50 \% \pm 5 \%$ relative humidity and $23 \pm 2{ }^{\circ} \mathrm{C}$.

Culture media and bacterial strains. Nine strains of $L$. monocytogenes previously described as isolated from raw ewe's milk cheeses $(12,13)$ and two reference strains, L. monocytogenes
NCTC 11994 (serotype 4b, soft cheese isolate) and Listeria innocua NCTC 11288 (serotype 6a), were used. For all these strains, the MIC values for nisin were 10 to $50 \mathrm{IU} / \mathrm{ml}$ at $\mathrm{pH} 5.5$ and 50 to $100 \mathrm{IU} / \mathrm{ml}$ at $\mathrm{pH} 6.8$. The cultures were maintained at $-80^{\circ} \mathrm{C}$ in BBL Trypticase soy broth (Becton Dickinson, Sparks, MD) containing $10 \%$ (vol/vol) glycerol and subcultured twice at $37^{\circ} \mathrm{C}$ 18 to $24 \mathrm{~h}$ before use in tryptone soy broth with yeast extract and glucose (TSBYEG), which contained $30 \mathrm{~g} /$ liter tryptone soya broth, $3 \mathrm{~g} /$ liter yeast extract, and $10 \mathrm{~g} /$ liter dextrose (Oxoid, Basingstoke, UK).

Antimicrobial agar diffusion assay. Films were aseptically cut into discs (6-mm diameter) and placed on the surface of plates of Trypticase soy agar containing yeast extract and glucose (TSAYEG), which contained $15 \mathrm{~g} /$ liter agar (Oxoid) more than TSBYEG, adjusted to $\mathrm{pH} 6.2$ with $\mathrm{HCl}$. The plates were previously inoculated with a swab of an 18-h culture of each test strain. After $24 \mathrm{~h}$ of incubation at $37^{\circ} \mathrm{C}$, the zones of the inhibition formed around the film discs were measured with the same micrometer used to measure film thickness. The assay was done in triplicate.

Statistical analysis. Data were analyzed with version 14.0 of the SPSS program (SPSS Inc., Chicago, IL). The Scheffé multiple range test $(P<0.05)$ was used to detect differences between mean values of film properties.

\section{RESULTS AND DISCUSSION}

Selection of type and concentration of organic acids. WPI-glycerol (Gly) solutions and films made with 1.5 and $3.0 \%(\mathrm{wt} / \mathrm{vol})$ concentrations of several organic acids were tested. With citric, acetic, malic, formic, ascorbic, fumaric, and lactic acids at 1.5 and $3.0 \%$, the mean ( \pm standard deviation $[\mathrm{SD}]) \mathrm{pH}$ of the resulting solutions was $3.23 \pm$ 0.43 (Table 1). Because acids become very weak when the target $\mathrm{pH}$ is lower than the $\mathrm{pK}_{\mathrm{a}}$ value, citric and malic acids (with $\mathrm{pK}_{\mathrm{a}}$ values of 3.13 and 3.40 , respectively) were most effective at lower $\mathrm{pH}$ values (around 3 ) than were acetic acid (pKa of 4.76) and ascorbic acid (pKa of 4.17).

Despite the incorporation of $3 \%$ glycerol as a plasticizer, films made with 1.5 and $3.0 \%$ formic acid, 1.5 and $3.0 \%$ acetic acid, 1.5 and $3.0 \%$ fumaric acid, $1.5 \%$ ascorbic acid, and $1.5 \%$ citric acid were not viable because of extreme brittleness (Table 2), so these types of films were eliminated from the study. The WPI-Gly films with 3.0\% ascorbic acid had a brown color and also were eliminated. Some influence of the nature of the acid molecule on the mechanical properties of the films was expected. Cagri et al. (5) reported that organic acids might have a plasticizing effect because they are small molecules with hydroxyl groups. Among the acids studied, citric, malic, and lactic acids have four, three, and two hydroxyl groups, respectively, and acetic and formic acids have only one hydroxyl group each. Hydroxyl groups of the plasticizer replace polymer-polymer interactions by developing polymer-plasticizer hydrogen bonds, which probably explains the higher elongation values for the films produced with citric and malic acids (Table 2).

With $1.5 \%$ acetic acid and $1.5 \%$ ascorbic acid, the whey proteins started to precipitate, and the solutions became white and opaque, forming thick gels that could not 
TABLE 1. Effect of various organic acids on pH, first Newtonian limiting viscosity, storage modulus, loss modulus, and loss tangent of the whey protein isolate film solutions plasticized with glycerol

\begin{tabular}{|c|c|c|c|c|c|c|}
\hline Acid, \% (wt/vol) & $\mathrm{pH}$ & Visual analysis & $\begin{array}{l}\text { Viscosity }\left(\eta_{0}\right) \\
(P a \cdot s)^{a}\end{array}$ & $\begin{array}{c}\mathrm{G}^{\prime}(\mathrm{Pa}) \text { storage modulus } \\
\quad(f=0.01 \mathrm{~Hz})\end{array}$ & $\begin{array}{l}\mathrm{G}^{\prime \prime}(\mathrm{Pa}) \text { loss modulus } \\
(f=0.01 \mathrm{~Hz})\end{array}$ & $\begin{array}{l}\tan (\delta) \\
\left(\mathrm{G}^{\prime \prime} / \mathrm{G}^{\prime}\right)\end{array}$ \\
\hline Acetic, $1.5 \%+$ lactic, $1.5 \%$ & 3.27 & Viscous & $73.09 \pm 19.43$ & $6.4 \times 10^{-1}$ & $5.4 \times 10^{-1}$ & $8.5 \times 10^{-1}$ \\
\hline $\begin{array}{l}\text { Lactic, } 1.5 \% \\
\text { Lactic, } 3.0 \%\end{array}$ & $\begin{array}{l}3.34 \\
2.92\end{array}$ & $\begin{array}{l}\text { Fluid } \\
\text { Viscous }\end{array}$ & $\begin{array}{r}16.41 \pm 23.04 \\
650.00 \pm 43.13\end{array}$ & $\begin{array}{l}1.9 \times 10^{-5} \\
1.2 \times 10^{0}\end{array}$ & $\begin{array}{l}3.4 \times 10^{-3} \\
9.4 \times 10^{-1}\end{array}$ & $\begin{array}{l}1.8 \times 10^{2} \\
7.8 \times 10^{-1}\end{array}$ \\
\hline $\begin{array}{l}\text { Malic, } 1.5 \% \\
\text { Malic, } 3.0 \%\end{array}$ & $\begin{array}{l}3.18 \\
2.76\end{array}$ & $\begin{array}{l}\text { Fluid } \\
\text { Fluid }\end{array}$ & $\begin{aligned} 23.65 & \pm 17.18 \\
0.20 & \pm 0.01\end{aligned}$ & $\begin{array}{l}6.3 \times 10^{-2} \\
3.0 \times 10^{-5}\end{array}$ & $\begin{array}{l}1.4 \times 10^{-1} \\
5.1 \times 10^{-3}\end{array}$ & $\begin{array}{l}2.2 \times 10^{0} \\
1.7 \times 10^{2}\end{array}$ \\
\hline $\begin{array}{l}\text { Citric, } 1.5 \% \\
\text { Citric, } 3.0 \%\end{array}$ & $\begin{array}{l}3.37 \\
2.90\end{array}$ & $\begin{array}{l}\text { Viscous } \\
\text { Viscous }\end{array}$ & $\begin{array}{c}5,622.29 \pm 378.25 \\
42.16 \pm 2.88\end{array}$ & $\begin{array}{l}1.8 \times 10^{1} \\
3.0 \times 10^{-1}\end{array}$ & $\begin{array}{l}7.8 \times 10^{0} \\
2.6 \times 10^{-1}\end{array}$ & $\begin{array}{l}4.4 \times 10^{-1} \\
8.7 \times 10^{-1}\end{array}$ \\
\hline $\begin{array}{l}\text { Formic, } 1.5 \% \\
\text { Formic, } 3.0 \%\end{array}$ & $\begin{array}{l}2.78 \\
2.48\end{array}$ & $\begin{array}{l}\text { Viscous } \\
\text { Viscous }\end{array}$ & $\begin{array}{l}0.99 \pm 0.15 \\
8.07 \pm 0.86\end{array}$ & $\begin{array}{l}2.5 \times 10^{-5} \\
5.9 \times 10^{-2}\end{array}$ & $\begin{array}{l}8.3 \times 10^{-3} \\
1.2 \times 10^{-1}\end{array}$ & $\begin{array}{l}3.3 \times 10^{2} \\
2.0 \times 10^{0}\end{array}$ \\
\hline $\begin{array}{l}\text { Acetic, } 1.5 \% \\
\text { Acetic, } 3.0 \%\end{array}$ & $\begin{array}{l}3.88 \\
3.58\end{array}$ & $\begin{array}{l}\text { Viscous } \\
\text { Viscous }\end{array}$ & $\begin{array}{l}\mathrm{ND}^{b} \\
\mathrm{ND}\end{array}$ & $\begin{array}{l}\text { ND } \\
\text { ND }\end{array}$ & $\begin{array}{l}\text { ND } \\
\text { ND }\end{array}$ & $\begin{array}{l}\text { ND } \\
\text { ND }\end{array}$ \\
\hline $\begin{array}{l}\text { Fumaric, } 1.5 \% \\
\text { Fumaric, } 3.0 \%\end{array}$ & $\begin{array}{l}3.21 \\
3.11\end{array}$ & $\begin{array}{l}\text { Viscous } \\
\text { Viscous }\end{array}$ & $\begin{array}{l}\text { ND } \\
\text { ND }\end{array}$ & $\begin{array}{l}\text { ND } \\
\text { ND }\end{array}$ & $\begin{array}{l}\text { ND } \\
\text { ND }\end{array}$ & $\begin{array}{l}\text { ND } \\
\text { ND }\end{array}$ \\
\hline Ascorbic, $1.5 \%$ & 4.01 & Viscous & ND & ND & ND & ND \\
\hline Ascorbic, $3.0 \%$ & 3.66 & Fluid & ND & ND & ND & ND \\
\hline
\end{tabular}

${ }^{a}$ Values are means $\pm \mathrm{SD}(n \geq 2)$.

${ }^{b} \mathrm{ND}$, not determined.

be spread to form films. All the other films were transparent. The $\mathrm{pH}$ values of the WPI-Gly film solutions of those two acids were 3.88 and 4.01 , respectively (Table 1 ), close to the isoelectric point $(\mathrm{pI})$ of two major constituents of the whey protein ( $\beta$-lactoglobulin and $\alpha$-lactalbumin; isoelectric points of 5.2 and 4.5 to 4.8 , respectively). The resulting gel was more rigid, in contrast to the more spreadable solution obtained when the $\mathrm{pH}$ of the solutions was far from the $\mathrm{pI}$, corresponding to the $\mathrm{pH}$ of minimum water-holding capacity and low solubility (1). Electrostatic interactions around the $\mathrm{pI}$ are responsible for protein aggregation, and consequently the proteins are less flexible and therefore less prone to form a cohesive film (7). As reported by De Wit (7), we found that WPI-Gly film solutions with $\mathrm{pH}$ values lower than 3.5 were completely transparent.

Under small-amplitude oscillatory stress, the WPI-Glyacid film solutions exhibited a predominantly viscous behavior or a weak gel behavior with $\mathrm{G}^{\prime}$ slightly higher than $\mathrm{G}^{\prime \prime}$ (Table 1). When the concentration of organic acids increased from 1.5 to $3.0 \%$, an increase of apparent viscosity with lactic and formic acids and a decrease with malic and citric acids were observed. These results are in agreement with the changes seen in the storage modulus $\left(\mathrm{G}^{\prime}\right)$ and loss modulus $\left(\mathrm{G}^{\prime \prime}\right)$ in the small-amplitude oscillatory stress testing. This finding was attributed to the different number of hydroxyl groups from the acids, which interfere with the protein matrix by introducing hydrogen bridging, thus increasing flexibility and decreasing structure and hence viscosity. The overall results of apparent viscosity ranged from $0.20 \pm 0.01 \mathrm{~Pa} \cdot \mathrm{s}$ for $3.0 \%$ malic acid-based film solutions and to 5,622.29 $\pm 378.25 \mathrm{~Pa} \cdot \mathrm{s}$ for $1.5 \%$ citric acid-based film solutions (Table 1).

According to Resch et al. (14), $\beta$-lactoglobulin gels formed at $\mathrm{pH}<\mathrm{pI}$ have weak mechanical properties, associated with inhibition of disulfide bonding, compared with those of gels formed at $\mathrm{pH}>\mathrm{pI}$, which exhibit strong elastic properties. Nevertheless, we observed a wide range of behavior according to the type and concentration of the

TABLE 2. Effect of various organic acids on mechanical properties, visual aspects, and thickness of low-pH whey protein isolate films plasticized with glycerol $^{a}$

\begin{tabular}{|c|c|c|c|c|c|c|}
\hline Acid, \% (wt/vol) & Aspect & $\begin{array}{l}\text { Tensile stress } \\
\quad(\mathrm{MPa})\end{array}$ & $\begin{array}{c}\text { Elongation at break } \\
(\%)\end{array}$ & $\begin{array}{l}\text { Puncture stress } \\
\text { (MPa) }\end{array}$ & $\begin{array}{l}\text { Elongation at puncture } \\
(\%)\end{array}$ & $\begin{array}{l}\text { Thickness } \\
(\mu \mathrm{m})\end{array}$ \\
\hline \multicolumn{7}{|l|}{ Acetic, $1.5 \%$} \\
\hline+ lactic, $1.5 \%$ & Extensible & $0.51 \pm 0.23 \mathrm{~A}$ & $2.22 \pm 1.05 \mathrm{AB}$ & $0.59 \pm 0.20 \mathrm{AB}$ & $1.97 \pm 0.28$ в & $96 \pm 9 \mathrm{~A}$ \\
\hline Lactic, $1.5 \%$ & Extensible & $1.85 \pm 0.87 \mathrm{CD}$ & $1.21 \pm 0.45 \mathrm{~A}$ & $0.75 \pm 0.18 \mathrm{BC}$ & $2.07 \pm 0.36$ в & $130 \pm 27 \mathrm{D}$ \\
\hline Lactic, $3.0 \%$ & Extensible & $1.32 \pm 0.22 \mathrm{BC}$ & $3.10 \pm 0.74$ в & $0.83 \pm 0.17 \mathrm{C}$ & $1.05 \pm 0.27 \mathrm{~A}$ & $127 \pm 18 \mathrm{CD}$ \\
\hline Malic, $1.5 \%$ & Extensible & $1.89 \pm 0.85 \mathrm{CD}$ & $2.08 \pm 0.65 \mathrm{AB}$ & $0.64 \pm 0.14 \mathrm{ABC}$ & $2.10 \pm 0.46$ в & $109 \pm 14 \mathrm{ABC}$ \\
\hline Malic, $3.0 \%$ & Extensible & $1.19 \pm 0.18$ в & $9.03 \pm 2.86 \mathrm{C}$ & $0.50 \pm 0.20 \mathrm{~A}$ & $5.52 \pm 0.74 \mathrm{D}$ & $125 \pm 11 \mathrm{BCD}$ \\
\hline Citric, $1.5 \%$ & Brittle & $\mathrm{ND}^{b}$ & ND & ND & ND & ND \\
\hline Citric, $3.0 \%$ & Extensible & $1.96 \pm 0.21 \mathrm{D}$ & $8.3 \pm 1.09 \mathrm{C}$ & $0.76 \pm 0.14 \mathrm{BC}$ & $3.72 \pm 0.31 \mathrm{C}$ & $106 \pm 9 \mathrm{AB}$ \\
\hline
\end{tabular}

${ }^{a}$ Values are means $\pm \mathrm{SD}(n \geq 15)$. Within a column, means with different letters are significantly different $(P<0.05$, Scheffé test).

${ }^{b} \mathrm{ND}$, not determined (brittle films). 
organic acid incorporated into the WPI-Gly solutions, all with $\mathrm{pH}<\mathrm{pI}$. These variations in the rheological properties, which were observed when different organic acids interacted with whey proteins in the film matrix, are not easily understood because they depend on temperature, $\mathrm{pH}$, ionic strength, whey protein concentration, and the nature and concentration of other solids (7). Because the temperature and the concentrations of the whey protein and glycerol were the same, the variations in the rheological properties are likely the result of differences in the ionic strength of the solutions, the nature of organic acid, and $\mathrm{pH}$.

The results of mechanical analysis ranged from $0.51 \pm$ 0.23 to $1.96 \pm 0.21 \mathrm{MPa}$ for tensile stress and $0.50 \pm 0.20$ to $0.83 \pm 0.17 \mathrm{MPa}$ for puncture stress (Table 2). These values for the low-pH films are substantially lower than that reported previously for high-pH films (5). A low-pH environment would likely prevent disulfide bond formation in the protein matrix, thereby weakening the film structure. Our results for tensile stress are similar to those reported by Sothornvit et al. (18); however, the results for elongation percentage are 10-fold lower. In general, an association between an increase in elongation percentage and a decrease in tensile stress was observed with the increase of organic acid concentration from 1.5 to $3.0 \%$.

The study on the effect of various organic acids (at 1.5 and $3.0 \%$ ) on antimicrobial properties of whey protein films revealed that the films made with $1.5 \%$ citric acid and 1.5 and $3.0 \%$ formic acid had no zones of inhibition on the agar plates; antimicrobial activity was evident only directly under the disc, although the $\mathrm{pH}$ of the WPI-Gly-formic acid solutions tended to be lower. The films made with $3 \%$ malic, lactic, and citric acid (with 3.67-, 2.51-, and 2.89-mm zones of inhibition, respectively) had greater inhibitory effects than did films with the same acids at $1.5 \%$ (1.83-, $0.50-$, and 0.0-mm zones of inhibition, respectively).

According to the overall results, WPI-Gly film solutions acidified with malic, lactic, and citric acids at $3.0 \%$ (wt/vol) were selected for evaluation in a subsequent assay with and without the lantibiotic nisin, and these results were compared with those for WPI-Gly film solutions made with $3.0 \%$ (wt/vol) $2 \mathrm{~N} \mathrm{HCl}(\mathrm{pH} 3.13)$ as the $\mathrm{pH}$ control.

Antimicrobial properties of films made with acids (3.0\%) and nisin. The incorporation of $50 \mathrm{IU} / \mathrm{ml}$ nisin in WPI-Gly films acidified with malic, lactic , and citric acids resulted in a significant increase $(P<0.05)$ in the zones of inhibition, indicating a synergistic antimicrobial effect of nisin plus malic or citric acid (Fig. 1) when applied to $L$. monocytogenes and L. innocua strains on TSAYEG at $\mathrm{pH} 6.2$, the usual $\mathrm{pH}$ of the rind of Castelo Branco cheese (13). The enhanced effect could be due to fact that the citric, malic, and lactic acids can take advantage of the pores previously opened by the nisin molecule and can penetrate more easily into the bacterial cell membrane. In addition, citric, lactic, and malic acids have chelating activity (10), and the performance of nisin can be improved by the effect of these chelators. Solubility of nisin is strongly dependent on $\mathrm{pH}$ and ionic strength, with highest solubility observed at low $\mathrm{pH}$ and low ionic strength (15). At $37^{\circ} \mathrm{C}$, the

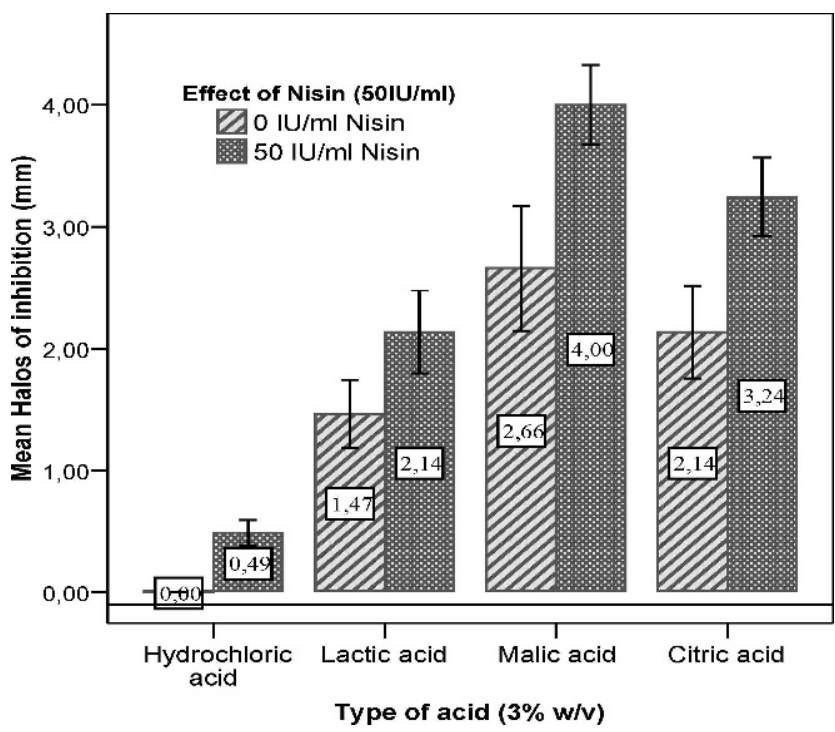

FIGURE 1. Antimicrobial activity of WPI-Gly films made with organic acids (3\%) and nisin (50 IU/ml) against strains of Listeria monocytogenes $(\mathrm{n}=10)$ and $\mathrm{L}$. innocua $(\mathrm{n}=1)$. The bars represent average triplicate values $(\mathrm{n}=33)$ for the zones of inhibition on TSAYEG ( $p H$ 6.2) with $95 \%$ confidence intervals. No inhibition of growth was observed around or under the discs prepared with $2 \mathrm{~N} \mathrm{HCl}(3 \%)$ without nisin.

temperature of incubation used in our assay, optimal molecular stability was recorded at $\mathrm{pH} 3$.

Antimicrobial activity of films with nisin plus malic, lactic, and citric acids were significantly different $(P<$ $0.05)$ from the control with nisin. No inhibition under or around the $3 \% \mathrm{HCl}$ discs without nisin ( $\mathrm{pH} 3.13$ ) was observed, in contrast with a clear zone of inhibition around the organic acid discs.

Organic acids with low molecular weight have higher antimicrobial activity. Nevertheless, in this study lactic acid had the lowest killing effect, followed by citric acid and malic acid. Citric and malic acids had the greatest inhibitory effect probably because the $\mathrm{pK}_{\mathrm{a}}$ of these acids is lower than the $\mathrm{pK}_{\mathrm{a}}$ of lactic acid, and consequently at similar concentrations, citric and malic acids tend to decrease the $\mathrm{pH}$ more than does lactic acid. The greater inhibitory effect also likely reflects the fact that the reduced ability of citric and malic acids to enter bacterial cells is compensated for by their enhanced ability to dissociate inside the cell and thus decrease internal $\mathrm{pH}$ (19). Citrate and malate ions have been reported to chelate polyvalent cations essential to microbial growth. Buchanan and Golden (4) observed that antimicrobial effects of malic acid against L. monocytogenes were similar to those of citric acid in brain heart infusion broth.

The highest average of zone of inhibition was $4.00 \pm$ $0.92 \mathrm{~mm}$, which was obtained using the combination of malic acid plus nisin. The next largest zone was obtained with citric acid plus nisin $(3.24 \pm 0.90 \mathrm{~mm})$. Eswaranandam et al. (8) also reported that malic and citric acids had greater antilisterial activity than did lactic acid when these acids were used at $2.6 \%$ in nisin-incorporated soy protein films with $0.9 \%$ glycerol.

Mechanical and rheological properties of film solutions made with acids $(\mathbf{3 . 0 \%})$ and nisin. The stress 


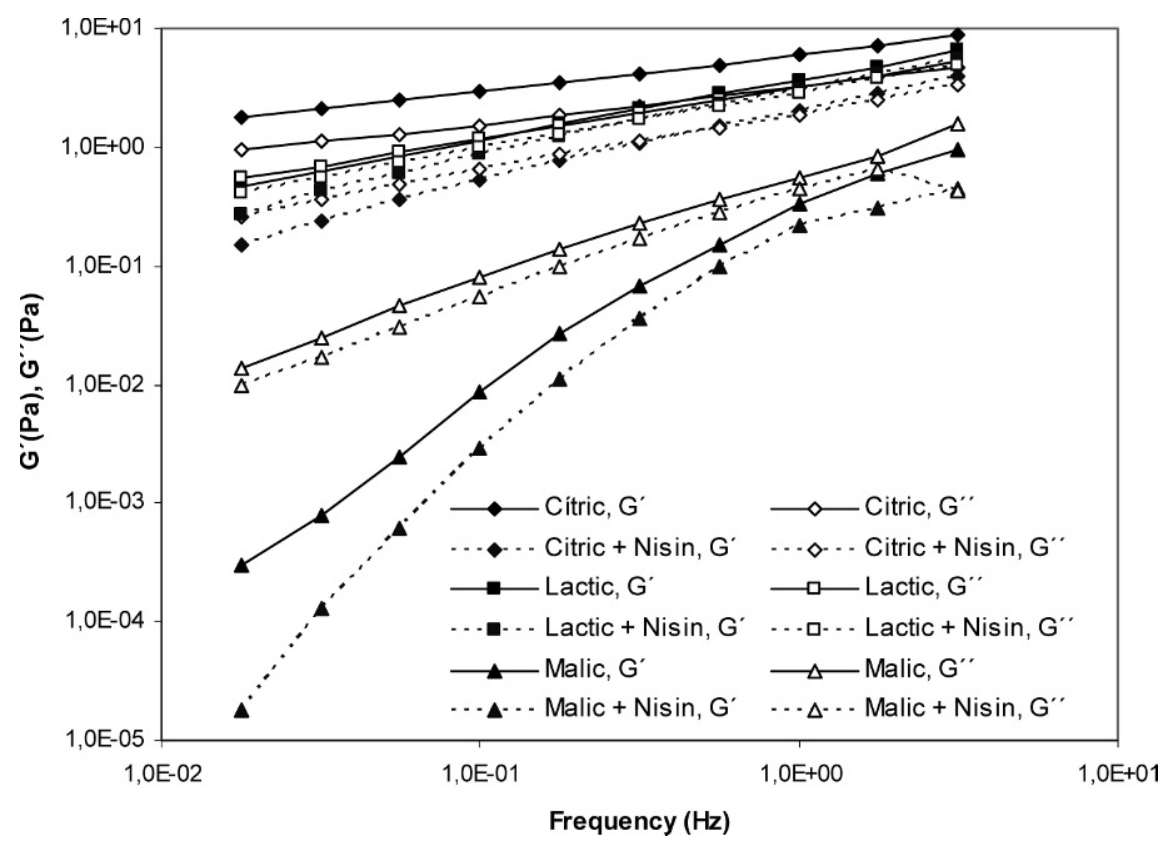

FIGURE 2. Mechanical spectra $\left(G^{\prime}\right.$ and $G^{\prime \prime}$ versus frequency) at $20^{\circ} \mathrm{C}$ of the WPIGly film solutions ( $\mathrm{pH}$ 3) acidified with $3.0 \%$ (wt/vol) citric, malic, and lactic acids without and with $50 \mathrm{IU} / \mathrm{ml}$ nisin.

range for linear viscoelasticity was determined by dynamic stress sweep at $1 \mathrm{~Hz}$. Film solution made with citric acid had the most structured network (followed by film solutions made with lactic acid and malic acids) with an extended linear region (data not shown). The mechanical spectra of the WPI-Gly film solutions made with malic, citric, and lactic acids were somewhat reduced by nisin incorporation (Fig. 2). WPI-Gly-citric acid solution without nisin had very weak gel-like behavior, with $\mathrm{G}^{\prime}$ slightly higher than $\mathrm{G}^{\prime \prime}$. The steady shear measurements (Fig. 3) were consistent with previous findings; this solution had stronger shear thinning behavior and a value of the first limiting viscosity closer to $10^{3} \mathrm{~Pa} \cdot \mathrm{s}$.

The whey protein solutions studied are non-Newtonian fluids. The viscosity $\left(\eta_{0}\right)$ of the solutions was reduced by the addition of nisin for solutions made with citric and lactic acids, but both solutions kept the shear thinning pattern. Nisin is a 3.4-kDa antimicrobial peptide composed of 34 amino acids (6) and disulfide and free thiol bonds. The lower viscosity observed after incorporation of nisin in the protein network may be due to competition for intermolecular bonds between whey-whey protein chains and whey- nisin protein chains, resulting in a reduction of interactions between the whey protein chains. High viscosities are unfavorable during preparation of films because it is more difficult to disperse the ingredients and eliminate air bubbles, which cause irregularities in the dried films. Thus, films made with malic acid had the best performance because they had a low apparent viscosity that was not reduced by the addition of nisin. The incorporation of nisin resulted in a significant increase $(P<0.05)$ in elongation percentage in films made with malic and citric acids (Table 3). Results from tensile and puncture stress tests were variable, but in general we did not find significant differences after the incorporation of nisin.

In conclusion, various interactions between organic acids and whey proteins within the films or film solutions resulted in variations in the antimicrobial, rheological, and mechanical properties. Nisin $(50 \mathrm{IU} / \mathrm{ml})$ improved the antilisterial effects of lactic, citric, and malic acids $(3.0 \%$, $\mathrm{wt} / \mathrm{vol}$ ) when used in whey protein films plasticized with glycerol (7.0\% WPI and 3.0\% Gly, wt/vol) against $L$. monocytogenes strains isolated from raw ewe's milk cheese in a disc diffusion assay on TSAYEG at pH 6.2. Films made

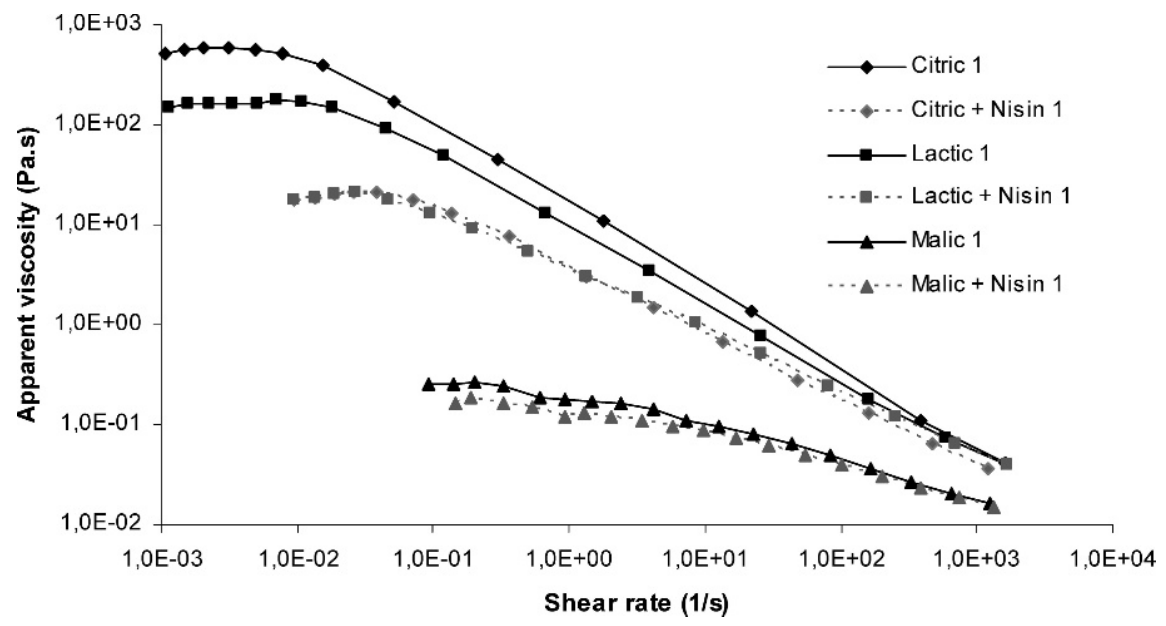

FIGURE 3. Apparent viscosity as a function of shear rate duplicates at $20^{\circ} \mathrm{C}$ for film solutions produced from whey protein isolate and glycerol acidified with various organic acids at $3.0 \%$ (wt/vol) without and with $50 \mathrm{IU} / \mathrm{ml}$ nisin. 
TABLE 3. Mechanical properties and thickness of low-pH whey protein isolate films with and without nisin ${ }^{a}$

\begin{tabular}{lccccc}
\hline \multicolumn{1}{c}{ Type of film $^{b}$} & Tensile stress $(\mathrm{MPa})$ & Elongation at break $(\%)$ & Puncture stress $(\mathrm{MPa})$ & Elongation at puncture $(\%)$ & Thickness $(\mu \mathrm{m})$ \\
\hline $2 \mathrm{~N} \mathrm{HCl}$ & $3.18 \pm 0.49 \mathrm{C}$ & $1.14 \pm 0.23 \mathrm{~A}$ & $0.34 \pm 0.09 \mathrm{BC}$ & $0.64 \pm 0.12 \mathrm{~A}$ \\
$2 \mathrm{~N} \mathrm{HCl}+$ nisin & $4.16 \pm 0.40 \mathrm{D}$ & $1.88 \pm 0.25 \mathrm{~A}$ & $0.31 \pm 0.08 \mathrm{AB}$ & $0.75 \pm 0.17 \mathrm{~A}$ & $95 \pm 10$ \\
Lactic acid & $2.20 \pm 0.24 \mathrm{~B}$ & $6.23 \pm 1.32 \mathrm{~B}$ & $0.44 \pm 0.08 \mathrm{CD}$ & $2.66 \pm 0.19 \mathrm{~B}$ & $92 \pm 8$ \\
Lactic acid + nisin & $2.11 \pm 0.20 \mathrm{~B}$ & $7.59 \pm 0.79 \mathrm{BC}$ & $0.27 \pm 0.04 \mathrm{AB}$ & $2.27 \pm 0.22 \mathrm{~B}$ & $86 \pm 6$ \\
Malic acid & $1.16 \pm 0.11 \mathrm{~A}$ & $8.87 \pm 1.15 \mathrm{C}$ & $0.23 \pm 0.03 \mathrm{~A}$ & $3.99 \pm 0.43 \mathrm{C}$ & $108 \pm 15$ \\
Malic acid + nisin & $1.38 \pm 0.21 \mathrm{~A}$ & $9.01 \pm 0.98 \mathrm{C}$ & $0.28 \pm 0.06 \mathrm{AB}$ & $4.86 \pm 0.53 \mathrm{D}$ & $97 \pm 8$ \\
Citric acid & $2.24 \pm 0.29 \mathrm{~B}$ & $7.01 \pm 1.38 \mathrm{BC}$ & $0.47 \pm 0.07 \mathrm{D}$ & $4.13 \pm 0.41 \mathrm{C}$ & $107 \pm 18$ \\
Citric acid + nisin & $2.31 \pm 0.35 \mathrm{~B}$ & $7.24 \pm 0.93 \mathrm{BC}$ & $0.46 \pm 0.08 \mathrm{D}$ & $4.68 \pm 0.47 \mathrm{D}$ & $82 \pm 9$ \\
\hline
\end{tabular}

${ }^{a}$ Values are means $\pm \mathrm{SD}(n \geq 15)$. Within a column, means with different letters are significantly different $(P<0.05)$.

${ }^{b}$ All acid concentrations were $3 \%(\mathrm{wt} / \mathrm{vol})$, and all nisin concentrations were $50 \mathrm{IU} / \mathrm{ml}$.

with malic acid plus nisin had the highest antimicrobial activity, and the rheological, mechanical, and antimicrobial properties indicate that these edible films could be used to wrap cheese and inhibit the growth of this pathogen, improving food safety.

\section{ACKNOWLEDGMENTS}

The authors gratefully acknowledge the Carbery Group (Cork, Ireland) for supplying whey protein isolate and Danisco Beaminster Ltd. (Beaminster, UK) for supplying nisin NP. C. Pintado was funded by a Ph.D. scholarship from the Programa de Desenvolvimento Educativo para Portugal (2/5.3/PRODEP/2003). Other funding came from the Portuguese Foundation for Science and Technology (project PTDC/AGR-ALI/67194/ 2006).

\section{REFERENCES}

1. Anema, S. G., S. Lauber, S. K. Lee, T. Henle, and H. Klostermeyer. 2005. Rheological properties of acid gels prepared from pressure- and transglutaminase-treated skim milk. Food Hydrocoll. 19:879-887.

2. Anonymous. 1995. European Parliament and Council Directive No 95/2/EC of 20 February 1995 on food additives other than colours and sweeteners. Off. J. Eur. Communities L 61:1-40.

3. Banerjee, R., and H. Chen. 1995. Functional properties of edible films using whey protein concentrate. J. Dairy Sci. 78:1673-1683.

4. Buchanan, R. L., and M. H. Golden. 1998. Interactions between $\mathrm{pH}$ and malic acid concentration on the inactivation of Listeria monocytogenes. J. Food Saf. 18:37-48.

5. Cagri, A., Z. Ustunol, and E. T. Ryser. 2001. Antimicrobial, mechanical, and moisture barrier properties of low $\mathrm{pH}$ whey protein-based edible films containing p-aminobenzoic or sorbic acid. J. Food Sci. 66:865-870.

6. Delves-Broughton, J. 2005. Nisin as a food preservative. Food Aust. 57:525-527.

7. De Wit, J. N. 1989. Functional properties of whey proteins, p. 285321. In P. F. Fox (ed.), Functional milk proteins. Elsevier Science Publishers Ltd., Barking, UK.

8. Eswaranandam, S., N. S. Hettiarachchy, and M. G. Johnson. 2004 Antimicrobial activity of citric, lactic, malic, or tartaric acids and nisinincorporated soy protein film against Listeria monocytogenes, Escherichia coli O157:H7, and Salmonella gaminara. J. Food Sci. 69:79-84.
9. European Food Safety Authority. 2005. Opinion of the Scientific Panel on Food Additives, Flavourings, Processing Aids and Materials in Contact with Food on a request from the Commission related to the use of polyvinyl alcohol as a coating agent for food supplements. Question number EFSA-Q-2005-017. EFSA J. 294:1-15.

10. Foster, R. J. 2005. Food product design: application pHood pHenomena. Available at: http://www.foodproductdesign.com/articles/ 463/463_0205AP.html. Accessed 28 November 2008.

11. McHugh, T. H., J.-F. Aujard, and J. M. Krochta. 1994. Plasticized whey protein edible films: water vapour permeability properties. $J$. Food Sci. 59:416-419.

12. Pintado, C. M. B. S., M. A. S. S. Ferreira, K. A. Grant, R. HalfordMaw, M. D. Hampton, and J. McLauchlin. 2007. Investigation of routes of contamination and persistence of Listeria monocytogenes in ewe's-milk cheese processing plants in Portugal. Presented at ISOPOL XVI-the 16th International Symposium on Problems of Listeriosis, Savannah, GA, 20 to 23 March 2007.

13. Pintado, C. M. B. S., A. Oliveira, M. E. Pampulha, and M. A. S. S. Ferreira. 2005. Prevalence and characterization of Listeria monocytogenes isolated from soft cheeses. Food Microbiol. 22:79-85.

14. Resch, J. J., C. R. Daubert, and E. A. Foegeding. 2005. The effects of acidulant type on the rheological properties of beta-lactoglobulin gels and powders derived from these gels. Food Hydrocoll. 19:851-860.

15. Rollema, H. S., O. P. Kuipers, P. Both, W. M. de Vos, and R. J. Siezen. 1995. Improvement of solubility and stability of the antimicrobial peptide nisin by protein engineering. Appl. Environ. Microbiol. 61:2873-2878.

16. Ryan, M. P., C. Hill, and R. P. Ross. 2001. Exploitation of lantibiotic peptides for food and medical uses, p. 193-242. In C. J. Dutton, M. A. Haxell, H. A. I. McArthur, and R. G. Wax (ed.), Peptide antibiotics: discovery, modes of action and applications. Marcel Dekker, New York.

17. Sothornvit, R., and J. M. Krochta. 2001. Plasticizer effect on mechanical properties of $\beta$-lactoglobulin films. J. Food Eng. 50:149155.

18. Sothornvit, R., C. W. Olsen, T. H. McHugh, and J. M. Krochta. 2007. Tensile properties of compression-molded whey protein sheets: determination of molding condition and glycerol-content effects and comparison with solution-cast films. J. Food Eng. 78:149-155.

19. Young, K. M., and P. M. Foegeding. 1993. Acetic, lactic and citric acids and $\mathrm{pH}$ inhibition of Listeria monocytogenes Scott A and the effect on intracellular pH. J. Appl. Bacteriol. 74:515-520. 
Reproduced with permission of the copyright owner. Further reproduction prohibited without permission. 